10.2478/genst-2018-0005

\title{
FOLKLORE STUDIES ON BIRTH RELATED CUSTOMS WITHIN THE BANAT COMMUNITY
}

\author{
OTILIA DANIELA ALEXIN \\ West University, Timișoara \\ 4, V. Pârvan Blvd, 300223 Timișoara \\ otilia.alexin81@e-uvt.ro
}

\begin{abstract}
Birth is perceived as a threshold, a milestone, and is best described as passing from one stage to another and from one status to another. This article aims to present the customs regarding the birth of a child, as they were preserved in the Banat folk mentality: the origin of the midwife and her role as mediator, the belief in the unfailing destiny foreseen by the book of fate, the rite of the first bath having a huge importance for the future of the child and a series of magic and religious acts meant to ward off the Evil forces that intend to harm the child and to restore the balance.
\end{abstract}

Keywords: child, destiny, mediator, midwife, rite.

\section{Introduction}

Out of the large category of family life customs - birth, wedding, burial - presented in detail by ethnologist and anthropologist Otilia Hedeşan (2005:16), the rite of birth is given a huge importance for being the starting point, as Gail Kligman (2005:127) also said: "Birth places humans on the path of life".

According to researcher Arnold Van Gennep, the promoter of the rites of passage theory, the birth stage is comprised of three rites: preliminary rites, of dissociation corresponding to the pregnancy stage; original rites, threshold rites that include the stage of delivery; and final rites, of aggregation, consisting of the postnatal customs together with the christening ritual (Van Gennep 1999:55).

This article aims to explore the category of the original rites, describing some of the Romanian people's beliefs related to the birth of a child, and also a number of final rites related to postnatal customs, excluding the christening ritual that would be discussed in a separate article. 


\section{Delivery Stage - Liminary Rites}

This stage of delivery is considered to be a a path of initiation, of passage from one stage to another: the child passes from the stage of fetus to the stage of new-born, from halflight to the light of the world, or from one status to another, while the woman passes from the status of pregnancy to the status of motherhood (Iana 1889:483).

In the mentality of the Romanian people, the first six weeks (40 days) after birth are considered to be an extremely vulnerable period for the mother and for the new-born, a period in which they are more exposed to the onslaught of evil forces like: wicked fairies, spirits, Samca and Baba Coaja, evil spirits, ghosts, vampires, beldams and so on. To defend her from such evil forces, the woman who had just given birth was not allowed to sleep during the day/night of delivery, because of the strong belief that evil spirits would come and haunt her until she dies, taking advantage of her weakness (Marian 2009:56).

\subsection{Magic Practices Used for Protection against Evil Forces}

In order to avoid confrontation with these evil spirits, Romanians resorted to magic practices that had a protection role. Rose hip - spinum album - (Marian 2009:56) was a plant believed to be a powerful repellent against demonic spirits, and was placed above the door or burnt in front of it. The rose hip missing, a red napkin was used instead, the same colour as the rose hip, since the Indo-Europeans believed that red had an apotropaic power of protection against enchantments and the evil eye (Pont-Humbert 1998:269-271). At the same time, the mother would wear a red piece of string around her neck and the child around the wrist so that they would be protected (Evseev 1999:410). Most of the birth rites were animist, indirect, sympathetic and positive.

Until the end of the twentieth century, in the Romanian villages of the Banat area the "old woman" gave birth at home, and in the delivery room, next to the bed, there were placed a club, a spinning wheel and an ax. (Nicolau, Huluţă 2000:181).

\subsection{Beliefs Related to the Book of Fate/Destiny}

Both upon birth and when a human being is dying all the Universe is present, because humans are considered to be part of the Universe and of the Earth. Thus, in the Romanian rural communities, there is the belief that, at childbirth, the name and the destiny of the child are written in a book of fate (Evseev 1999:473, Gorovei 2002:20); also the child is assigned a star, that accompanies her/him along her/his life till death, when the star falls from the sky. When 
life is hard, folks often say: “Oh, my stars!" (Praoveanu 2001:248; my translation). During the nights with clear sky, when a meteor falls ( "falling star"), people believe that the star of a person has set and that someone will die.

With regard to birth superstitions, researcher Aurel Iana, who has closely studied the Banat mountain region, in particular the Oraviţa-Maidan area (currently, Brădişorul de Jos), stated: "The person who is born on Easter day, when the church bells are rung, is a lucky person all his/her life" (Iana 1890:7; my translation).

So, children who were born during a holiday (Easter, Christmas), on Sundays, those who were born after midnight and those who were born with a caul (caput galeatum) were considered to be lucky. Being born with a caul was not auspicious in all regions, in some areas such babies were called "daredevils" (Radan Uscatu 2014:39), the belief being that after death they would become vampires.

To protect themselves from evil spirits, who would want to harm the infant or their mother, during the period between birth and christening, the mother's room and bed were sprinkled with holy water and every night a candlestick was lit next to the cradle of the newborn. (Marian 2009:57)

As the woman gave birth at home, assisted by the midwife, the first wish for the newborn was made by the midwife and was repeated every time when the new-born was facing an event for the first time, as, for example, the first bath. The first three wishes were good health, luck, and brains, then cheerfulness, and moral and psysical beauty.

\subsection{The Midwife}

The midwife ('moașă’ in Romanian, literally, 'old woman'), just like “old man”, sends us back to the origins of the nation, representing "the bridge" between the world of the ancestors, where the infant is believed to come from, and the world it entered. The midwife carries out the sacred and profane acts, fulfilling her mission to ensure the delivery of a healthy infant and also welcoming the new born into the family and paternal lineage. Because giving birth implies a lot of blood, after delivery, both mother and child were considered to be unclean and it is the midwife who bathes them both, in a first stage of the cleansing process.

\subsection{The First Bath of the Baby}

The rite of the first bath is strictly observed and it is believed to exert a huge influence on the child's destiny. The bathing tub was made of fir or linden wood, not from alder wood because of its negative impact on the future of the child, who would then wander among 
strangers all his/her life. Both the bathing tub and the pot where the water was heated up were preferred to be new, as the common belief was that "the sound made by the new pot would be similar to the clear, deep and pleasant voice of the new-born" (Marian 2009:68; my translation). The water was taken after sunrise and before sunset from a place with clear water, muddy water being a sign of trouble, and was each time taken from the same source (spring, well, river) so that the sleep of the new-born would not be troubled.

According to custom, the water of the first bath is sprinkled with holy water from Epiphany and also with incense to ward off the evil spirits. One or more silver coins are also laid in so that the baby can stay protected and loved by people just as the silver is; flowers/plants (basil, chamomile, mayweed, mint, peony) so that it would be beautiful, have rosy cheeks and be gentle like a flower (Evseev 1999:73); honey or sugar to be a smooth talker (Hedeşan 2001:16); keys to enter the world of knowledge; a mirror to be beautiful to the world; an egg to be healthy and wholesome like the egg; milk to be clean and white-skinned; a nut or a pebble to be resilient; bread to be a good person "as good as God's bread" (the Romanian equivalent for "as good as gold"): "dear as silver, sweet as honey, good as the bread, healthy as the egg, rosy-cheeked as the peony, attractive as the basil and white as milk" (Marian 2009:69-75; my translation). Sometimes, a pencil is added, as it is believed that the child will love to learn, a musical instrument so that it can be a good instrument player, and other objects symbolizing different trades (a hammer for boys, a needle for girls). In Banat, the custom was to warm the water drawn by the midwife from the spring with twigs gathered from the road so that the child would be a thrifty person.

The water from the first bath was thrown away before sunset in a safe, clean and isolated place, over flowers or at the bottom of a fruit bearing tree "so that the flesh could grow on it" (Hedeşan 2001:17; my translation), since it was believed to be inauspicious for it to be thrown away randomly.

In Romanian villages there is constant care to protect the new-born from evil spirits, therefore "the bathing tub is blown upon and then holy water is sprinkled over it [...] so that all the evil spirits go away, and in particular the female vampires". Also, for the purpose of protection, holy water is used for six weeks after birth, this being seen as the most vulnerable period for the infant (Marian 2009:76).

\subsection{Swaddling the Infant}

After bathing the new-born the next rite is that of swaddling. In the mentality of the Romanian people there is the belief that the newborn's clothes must not be purchased/made 
before the child's birth and then they must not be dried outside, over night, but they are to be taken inside before sunset so that the evil spirits cannot touch them. Also, there is the common belief that the infant's clothes had better not be turned inside out, so that the child would have a good life. In the past, the infant was swaddled in square pieces of cloth, the diaper was made of a thin cloth, the swaddle was woven out of wool dyed red, yellow, and blue, about two meters long, at one end having a cloth satchel containing incense, a silver coin, salt, garlic, powder and three small metal axes, about two centimeters in length, to protect the child from the evil spirits. The child would wear a cap.

In the Banat region there is the belief that the infant's wit and skills could be enhanced if its diapers were dried on a wagon wheel, placed near the fireplace, the mother or the midwife chanting: "May my nephew or niece, be as quick, bright and handy as the wheel is!" (Marian 2009:89, my translation).

As it is a well known fact that the new-born relies mainly on smell and touch in its first days of life, the infant is wrapped in clothes belonging to his/her mother or father. In time, this technique has been improved, so that today the skin-to-skin method is used (Simkin, Whalley, Keppler 2016:322), a method which allows the new-born to be held without clothes on its mother's or father's bare chest for the same reason: to adjust, to be fed and to acquire the feeling of comfort and safety.

After the swaddling, the infant is shown to the father who praises the midwife giving her money for her help and he is usually happier when a boy is born rather than a girl, a boy being seen as a successor of the lineage and a help around the household.

\subsection{Breastfeeding the New-Born}

The main concern of the mother, once the infant was bathed and swaddled, is breastfeeding, a process that is important not only for the feeding role it has but also for the psychological comfort it offers to the newcomer (Walker 2016:39). Since ancient times, the nourishing properties of the mother's milk and those of the colostrum, the milk the mother is producing the first days after giving birth, have been well-known. The child who is fed naturally, i.e. breastfed, is considered to be healthier and able to develop a more powerful affective bond with the mother (Wambach, Riordan 2015:536). Great importance is attached to the way breastfeeding is initiated: “when breastfeeding the child for the first time don't hold him/her on the left arm and don't feed him/her from the left breast, because all his/her life he/she will be a left-handed person, weak, clumsy, having no skills, no luck; but hold him/her on the 
right side and feed him/her from the right breast and he/she will be a right-handed person, strong, skillful, enjoying a blessed life" (Marian 2009:109; my translation).

\subsection{The Cradle}

The cradle of the new-born is best made of cherry tree wood. Its size depends on the needs of the mother: it is generally small so that the mother can carry it around from place to place, or to the field, and so that it could be hung from the ceiling or a tree branch; it can also be big, similar to a swing, for indoor use only.

\subsection{The "Molidva" Rite on the Eighth Day}

In the past, when women gave birth at home, shortly after delivery, even on the very first or the second day, the priest would come to the house of the new-born to carry out the small blessing of the water or to free the house. This water was used to sprinkle the infant, the mother and the midwife, and at the same time, the priest would read the prayers for cleansing the latter two. Due to the fact that this water is believed to have supernatural powers of protection and healing, it was poured in the first bath of the new-born until christening (Foundoulis 2008:117).

Nowadays, the custom is to prepare for the prayer on the eighth day. The etymology of the word is derived from the word "molitva", from the Slave languages, with the meaning of 'prayer', moliti - "a se ruga" - "to pray" (Dex 1998:647), with two alternative terms: "molitvă" or "molitfă" (Doom2 2005:684). This is a practice of the church, a prayer specific for the moment of the child's birth, with its origin in the Old Testament when our Lord, Jesus Christ, was brought to the temple on the eighth day (Luke 2:21), according to the Mosaic Law, in order to be cleansed by being cut around - circumcised (Leviticus 12:3) and to be given a name. Consequently, on the eighth day, the midwife takes clean water to the priest, and a handful of basil tied up with a red or white string for happiness and luck. The prayer also has the supernatural properties of healing, of calming and of protecting the infant from evil spririts and it is enacted until christening (Foundoulis 2008:158).

\subsection{Evil Eye Action}

The fear of the evil eye is very common among Romanians; people could cast the evil eye on the child simply by speaking. If during the pregnancy period the child is indirectly aimed, after the birth the evil eye becomes a direct action that could lead to the infant's illness or even death. The child upon whom the evil eye was cast would cry continuously, would not sleep or 
eat, so the child would be taken to a person who would whisper an incantation, or a person who could perform such incantations would come to the house.

Another method used to fight against the evil eye was to add white violets together with willow bark in the bathing water. Putting pieces of coal in the bathing water is also considered to be an efficient method (Marian 2009:77; 85-86).

To avoid the evil eye's unpleasant consequences, in the Banat region and not only, the new-born and the mother wear a red string around the wrist because, in the mentality of the community, "bright red [...] sheds its light upon all things and gives them its power (PontHumbert 1998:269-271), the power and protection of the blood shed on the cross by Jesus Christ. At the same time, red symbolizes vitality, energy, victory, happiness and the harmony of the universe.

Also for the purpose of warding off the evil eye, certain bright-coloured objects are placed in different places in the house and through their unusual position, they are meant to attract the attention of evil spirits, thus sparing the child.

Spitting is another way of protection against the evil eye. The guests who come to see the new-born spit towards him/her saying: "God bless you!". Even in the bathing water the mother or the midwife would spit after the child was taken out of the tub. Also, the saliva is used together with clay to prepare a paste with magic power that can ward off the evil eye (Marian 2009:76).

\subsection{Postnatal Customs}

The new-born is part of the community, all the final rites being observed so that it would be welcomed and in agreement with the mentality of the community and with the unwritten laws of the Universe:

The relation with the palpable present, with the people in the community is reestablished constantly rendering real the events from the outsider's standpoint and reassuring the insider about the rigour of the rites when entering this world. We frequently see the magic acts against evil forces at work, or, on the contrary, we see that rites are not observed and attract - almost inexplicably - an imbalance" (Ştiucă 2000:84; my translation).

Villagers from the area of Oraviţa, the Banat mountain region, believe that, if in the first month of the new-born's life, the mother perceives unusual traits, which she thinks she might have attracted upon the child during her pregnancy because she was strongly impressed by 
something, she has to carry out a particular rite: on the first Sunday of the following month, during mass, she has to breastfeed the child for the first time on the room's threshold, concentrating on the thing she was so strongly impressed by and at the same time asking God to have mercy on her child. Then the infant has to be breastfed on the kitchen's threshold, and finally, under the house's eaves, on the very spot where the water is dripping, saying:

\footnotetext{
"May God, the Almighty, who created man in his own image, drive away from my son/daughter (the name of the child) all the bad habits and traits that are unnatural and not human, so that (the name of the child follows), remain untouched and as bright as the pure gold, like Mary, Mother of God, who left him as the dew in the field, as the star in the sky! Amen" (Marian 2009:23; my translation).
}

For this practice to work and have the expected results, and for the marks and unnatural traits to be sent away from the infant, the practice had to be repeated three times, on the first Sunday of the following month and then the next, up to three months.

In the rural area of the Banat mountain region, there is the belief that the new-born must not be left by itself until christening, because an adult's absence means there was nobody around to help him/her fight evil spirits. A practical reason for this would be that the syndrome of sudden death can occur, the infants could easily suffocate or choke with saliva or vomit (Simkin, Whalley, Keppler 2016:351). If, however, circumstances require the infant to be left by itself for a short period of time, a few objects are put by his/her side: a knife or a metal object, incense, a pair of scissors, a prayer book and a spoon; people believed they would "feed the child and keep him/her safe" (Iana 1890:483, my translation), the above mentioned objects were considered to have the role of the infant's secret guardian (Iana 1890:483). The apotropaic properties of iron have been known since ancient times, according to Simion F. Marian: "Iron has healing powers. It works against witchcraft, in the case of old people and children alike" (Marian 2009:56, my translation). Starting with the christening moment, the child is protected by God and is given a guardian angel.

\subsection{Choosing the New-Born's Name}

The process of welcoming the child into the new world, together with the first bath and breastfeeding also includes choosing the name for the new-born by the parents, on the eighth day, when they go to church to say the prayer for this moment. The name is usually chosen according to the Orthodox religious calendar: the custom is that the new-born will receive the name of the saint celebrated close to the date of birth in order to be protected by that saint. 
Sometimes the child is given a second name, that of the father/ grandfather/ godfather, or that of the mother/ grandmother/ godmother, although, according to Romanians, it is believed that children with two names are more uncertain and more hesitant when having to make a choice. According to folk mentality, the new-born is given a nickname/ an alternative name, that hides the real one, protecting the child against the evil eye. In the countryside each family in the village has a nickname which is known as 'the nickname of the family' (Gorovei 2002:39).

\section{Conclusion}

It has been noticed that during the ritual of birth there is constant concern for people to observe the rites of protection and foretelling, the original rites, of passage, and the final rites, of welcoming the child in the community and of re-inserting the mother in the social life of the community that, through their magic acts, fight against evil forces, restoring the balance.

Although over time the rite of delivery has undergone certain changes, the room in the house being replaced by a maternity ward, the customs were passed from one generation to the next, the midwife, the godfather and the godmother being still active during the ritual. To be godparent to a child still represents an honour and the mentality according to which the godfather deserves at least the same respect as a parent is very much alive. This could be one of the reasons why in the Banat communities the godfather is never replaced, families preserving the same godparent over five-six generations. Throughout the entire process the midwife plays an important role, that of "a connecting bridge", a mediator between the world of the ancestors, where the child is coming from, and the new world, where he/she enters, between the sacred world of the Fairy Godmothers and the profane one of the humans. She plays a vital role in accustoming the new-born with the new environment.

Consequently, birth is a threshold, a milestone, a passage from one stage to another (the child passes from the stage of fetus to that of new-born), from one status to another (the woman passes from the status of pregnancy to that of motherhood), during which the rituals of human passage are intertwined with the rituals of cosmic passage, human existence being closely related to the Universe.

\section{References:}

Evseev, Ivan. 1999. Enciclopedia semnelor şi simbolurilor culturale. Timişoara: Editura Amarcord.

Foundoulis, Ioannis. 2008. Dialoguri liturgice. Răspunsuri la probleme liturgice. Vol.I. Bucureşti: Editura Bizantină.

Gorovei, Artur. 2002 (1909). Datinile noastre la naştere şi la nuntă. Bucureşti: Editura Paideia. Hedeşan, Otilia. 2001. Folclorul. Ce facem cu el? Timişoara: Editura Universităţii de Vest. 
Hedeşan, Otilia. 2005. Lecţii despre calendar. Curs de folclor. Timişoara: Editura Universităţii de Vest. Iana, Aurel. 1889. "Credinţe la naşteri, din părţile Oraviţei.” Familia XXV(41):483.

Kligman, Gail. 2005 (1997). Nunta mortului. Ritual, poetică şi cultură populară în Transilvania. Iaşi: Editura Polirom.

Marian, Simion Florea. 2009 (1893). Naşterea la români. Studiu etnografic. Bucureşti: Editura Saeculum Vizual.

Nicolau, Irina; Huluţă Carmen. 2000. Credinţe şi superstiţii româneşti. Bucureşti: Editura Humanitas.

Pont-Humbert, Cathérine. 1998 (1996). Dicţionar universal de rituri, credinţe şi simboluri. Bucureşti: Editura Lucman.

Praoveanu, Ioan. 2001. Etnografia poporului român. Bucureşti: Editura Paralela 45

Radan Uscatu, Miliana-Radmila. 2014. Botezul, nunta şi funeraliile la caraşoveni. Timişoara: Editura Universităţii de Vest.

Simkin, Penny: Whalley, Janet; Kepller, Ann. 2016. Pregnancy, Childbirth and the Newborn: The Complete Guide. Minnetonka: Meadowbrook Press.

Ştiucă, Narcisa Alexandra. 2000. Transcrieri infidele. Bacău: Editura Corgal Press.

Van Gennep, Arnold. 1996 (1909). Riturile de trecere. Iaşi: Editura Polirom.

Walker, Marsha. 2016 (2006). Breastfeeding Management for the Clinician. Burlington: Jones and Barlett Publishers.

Wambach, Karen; Riordan, Jan. 2015 (1993). Breastfeeding and Human Lactation. Burlington: Jones and Barlett Publishers.

***1998 (1975). Dicţionarul explicativ al limbii române (DEX). Second edition. Bucureşti: Academia Română, Institutul de lingvistică „Iorgu Iordan”.

***2005 (1982). Dicţionarul ortografic, ortoepic şi morfologic al limbii române. Second edition. Bucureşti: Academia Română, Institutul de Lingvistică “Iorgu Iordan-Al. Rosetti”. 